\title{
ASSERTING THE DOMINANCE OF IGBO CULTURAL MOTIFS IN NOLLYWOOD COSTUMES: AN ANALYSIS OF SELECT NOLLYWOOD FILMS
}

\author{
Mary Nkechi Okadigwe* \\ http://dx.doi.org/10.4314/og.v15i1.13s
}

\begin{abstract}
It is taken for granted that Igbo cultural motifs are pivotal to the formation of Nollywood costumes. The researcher thus finds the examination of the evolution of Nollywood costumes an important subject that requires urgent attention. The aim of this examination is to assert the dominance of Igbo cultural motifs in Nollywood costumes. Qualitative research method was adopted for the research. Using ethnographic research approach, the researcher had sought the opinions of experts in traditional Igbo aesthetics and symbols. The study finds semiotic theory appropriate model for the costume analysis. Findings from this research reveal that Igbo dress culture was pivotal to the development of Nollywood costumes and has continued to play significant roles in costuming Nollywood characters. This research recommends that Nollywood costume designers should focus more on the communicative essence of costumes and their effectiveness in preserving culture. Costume designers should also be given ample time and budget to carry out an ethnographic research in order to employ motifs appropriately. The case studies used for the research were Ijele, My Rising Sun, Living in bondage and The Priestess.
\end{abstract}

Keywords: Igbo cultural motifs, Costumes, Nollywood, Dominance, Dress culture, Prototype.

\section{Introduction}

It is axiomatic that Igbo cultural motifs have contributed to the formation and evolution of Nollywood costumes. It then appears that the dominant place of Igbo cultural motifs in Nollywood costumes has not been fully appreciated. Although much has been written on various aspects of Nollywood costumes, it appears that none of the existing researches has given credence to the contributions of Igbo cultural motifs to the formation of Nollywood costumes. While 
researches abound that are devoted to Nollywood costumes and the contributions of various cultures to the development of the costumes of the Nollywood; it appears that not much attempt have been made by such researches at documenting the history of Nollywood costumes and how Igbo motifs have led to its evolution. The researcher thus sees it as a subject of urgent concern to examine the evolution of Nollywood costumes with the aim of asserting the dominance of Igbo cultural motifs in Nollywood costumes. This research thus examined the factors that informed the adaptation and dominance of Igbo motifs in Nollywood costumes. Accounts on the emergence of Nollywood film industry were significant signposts through which this aim was achieved. With the help of semiotic theory, the research has carefully investigated and interpreted the socio-cultural significance of the various colours, patterns, style and mass of Igbo attires which have been adopted by Nollywood designers.

\section{Theoretical Framework}

The researcher utilizes semiotics theory in analyzing Nigerian films in order to present a critical interpretation of the elements of costumes in Nollywood costumes. Semiotics, the study of signs and symbols is a theory developed in Linguistics by Ferdinand de Saussure for studying the structure and meaning of language. In the tradition of semiotics developed by Saussure, the relation between a costume (the signifier) and its meaning (the signified) is seen as being essentially arbitrary and motivated only by social convention. Semiotics became a major approach to cultural studies in the 1960s, mainly as a result of the work of Roland Barthes. Adapting Saussure's model to the study of cultural phenomena other than language, Barthes developed his Fashion System in 1967. In Fashion System, Barthes shows how the adulteration of signs could easily be translated into words. Barthes' Fashion System questions the overall utility of demystifying culture for the masses; hence it drives into a search for individualistic meaning in art. Whereas, determinists like Aristotle saw things in terms of cause and effect, semiotics looks for signs and symbols. It challenges common sense, which believes that things have one meaning and that this meaning is absolute. Saussure and Barthes were all interested in discovering what constitute a sign 
Okadigwe: Asserting the Dominance of Igbo Cultural ...

and they believe that the meaning generated by a sign is relative. Thus, to the two theoreticians, meaning is dynamic.

It seems therefore that film costume possesses no validity in its own right but is given signification by viewers through personal experience. And if a costume has no meaning in itself, but takes on meaning from its usage; it then can be argued that emerging Nollywood film costume design (which is an epitome ofthe continuous evolution of the Igbo dress culture), although a syncretism of motifs from diverse cultural background, has been accepted as Igbo costumes by Nollywood film viewers. If a costume is adequately given meaning by its usage, then most Nollywood costume have been assigned meaning by the virtue of their being used by Igbo people in the real world. Therefore, it is the sociocultural context of a film that imbues costumes with meanings.

\section{Brief History of Nollywood Costumes}

The various accounts of the history of Nollywood are pointers to the origin of costume in Nollywood. The origin of costume in Nollywood therefore goes back to the costuming of Living in bondage and its contemporaries. From introduction of costume culture in Nollywood, there can be found in various costumes traces of Igbo cultural motifs with the characters and narratives attesting to the cultural significations of these motifs in relation to the film milieu. We can infer a veritable example from Living in bondage. Although, some female characters are costumed in Western dresses (which is in consonance with Igbo dress culture of the time), the male characters are most times shown in traditional attires. There is an instance where Paulo is dressed in the famous isiagu jumper with a black bowler hat. It follows then that the first phase of costume culture in the history of Nollywood is an embodiment of Igbo cultural motifs.

Apart from the first phase films which were centered on themes such as the osu (outcaste syndrome), get rich-quickmentality, the industry expanded to include other genres that have national theme. Ayakoroma posits that, "In the bid to improve the circulation of video films beyond the Igbo enclave, Nnebue again pioneered productions in English with Glamour Girls (Onukafor, 1995)." (6) The theme of the film centers on the prevalent 
prostitution of Nigerian girls abroad. Thus English language Nollywood films were ushered in. Fortunately, the emergent English films were set in a world that is very familiar to the costume designers. So regular contemporary cloths were used to characterize the actors and actresses.

Another development of costume in Nollywood films comes with the introduction of the epic genre of Nollywood films. Nollywood epic films are clear depiction of ancient traditional society. The costumes of the earliest Nollywood films were modeled from the Igbo traditional clothes. Ijele exemplifies the dress code of the Igbo people of the ancient times. The film shows maidens costumed in mini wrappers with clothes wrapped around their breasts. Married women in Ijele (1999) wear two maxi wrappers. With one of the wrapper tired on the chests, while men tie anklelength wrappers. Beads and cowries are extensively used to adorn characters according to sex and social status.

The near-complete reliance on Igbo dress culture by Nollywood costume designers for inspiration continued for some time to be the practice amongst Nollywood costumiers until in recent time when the costumiers began to imbibe the art of syncretism in designing Nollywood costumes. This emerging costume culture appears to be a conglomeration of cultural motifs from diverse ethnic cultures in Nigeria. Yet, inspiration for the emerging costume culture could be traced to the dress culture of the contemporary Igbo people. The cultural dress of the Niger-Delta men seems to be the most popular among the contemporary Igbo men. The popularization of this dress culture among Igbo men might be as a result of the design bearing semblance with the design of the traditional Isiagu jumper of the Abiriba people of Abia state and Arondizuogu people of Imo state. This Woko jumper of Kalabari people popularly known as "senator" was popularized by the immediate past president of Nigeria, Goodluck Jonathan. According to Ejiofor, "In ancient times, it was worn over a fathom of wrapper, and it sustains accessories which include a head-gear...In contemporary times, the woko attire is worn over long pants with shoes to cover the feet." (63) This dress code has since then become the favourite dress code among Igbo men, and the same fashion was also adopted by Nollywood costume designers as shown in Better Tomorrow. For the women, iro and 
Okadigwe: Asserting the Dominance of Igbo Cultural ...

buba of the Yoruba people of South-West Nigeria has recently been modified and appear to be the favourite among Igbo women. Indian sari, embroidered chiffon and embroidered silk of the Indians have all become the favourite fabrics among women of South-East and South-South of Nigeria. Thus Nollywood film costume has largely been influenced by Igbo dress culture as these popular dress cultures have evidently been adopted into Nollywood film costume culture. (See Pictures 1, 2 and 3)

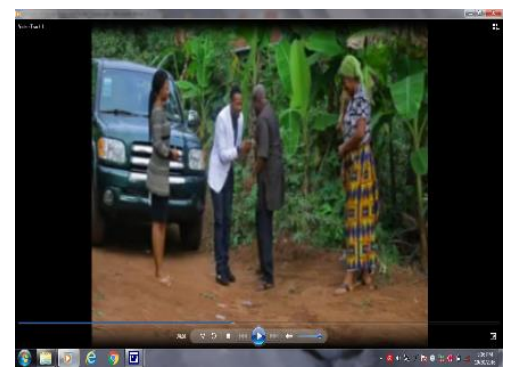

\section{Picture 1}

Picture 1 shows a woman and a man dressed in traditional Igbo costumes while the young man and maiden are costumed in modern Igbo cloths. The styles of their costumes signify their different marital status.

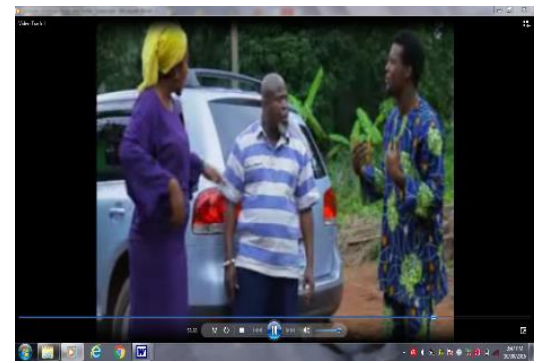

Picture 2: Characters costumed in modern Igbo cloths. Note that Igbo contemporary cloths are integration of motifs from different cultures. Although the buba worn by the woman is of Yoruba origin, 
Ogirisi: a new journal of African studies vol. 15s 2019

it has been adopted by contemporary Igbo women.

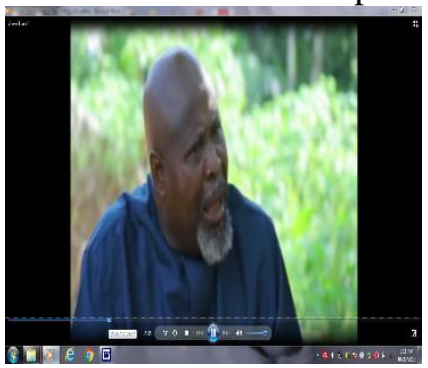

Picture 3 shows a character wearing senator. Although senator seems to be the most popular fashion among Nigerian males, it has exclusively been used by most Igbo bridegrooms during traditional marriage celebrations. Pictures 1, 2 and 3 were sourced from Ilochi Olisaemeka's Better Tomorrow 2016

\section{Igbo Cultural Motifs in Nollywood Films}

Amata Fred's Ijele is discussed here as an example of how signs generate meaning in Igbo costumes. There are a number of important ideas in Ijele (1999). One is that of love and destiny and the triumph of truth over deceit. The film shows Ijele, the protagonist embarking on so many dangerous journeys to save Ola whom he has been fated to marry even before her reincarnation.

Costumes in Ijele provide visual information about the Igbo traditional world, the period the film was set, as well as the film's socioeconomic, religious and political environment. With the aid of costumes Ijele telescoped and portray the ancient Igbo milieu. Dignified characters like the king, priestess and chief priest wear elaborate magnificent clothes and accessories. Distinction is made between married mothers and maidens, young men and father, titledmen and untitled-men, subjects and leader, sacred and secular, wrestlers and audience, farmers and hunters.

Igwe: Igwe in Ijele is usually referred to as EzeOdu. The film portrays him in a white akwete tied from under the right armpit and knotted at the left shoulder. Igwe's accessories are long red cap elaborately designed with feathers. The length of the cap and the elaborate feathers with which it was designed give the cap an 
Okadigwe: Asserting the Dominance of Igbo Cultural ...

elevated look which elicits honour. He is also wearing two strings of orange colour beads, arm-band made with silver and brass on both arms. He carries a white traditional hand-fan designed with traditional symbols on his left hand and a black horse-tail on his right hand.

The costumes of Igwe as described above convey information about the Igbo culture. Every item of costume described above adhered religiously to the traditional Igbo world view. His costumes also indicate his social status as a king. Akwete fabric is an Igbo cultural locally spun clothe. It is a symbol of wealth and good taste. Nza (horse-tail) is a mark of authority. Red cap is symbol of chieftaincy and portrays an Igbo traditional milieu. Arm-band indicates grandeur and strength. Akahs are also symbols of wealth.

On the day of Igba-mgba (wrestling festival), Igwe is magnificently dressed in george fabric, chequered in various colours, neck beads, wrist-beads, a crown (a mantle made in the Igbo fashion) intricately decorated with feathers, beads and other fanciful items. He also carries an $n z a$ to complement and complete his kingly status. In Ijele's Igba-mgba, Igwe is amongst the spectators, but his elaborate and richly made costume differentiates him from other spectator; marking him out as an important character.

It seems that the costume designer (Millicent Jack) just played with colours as we see Igwe usually robed in varied beautiful colours of akwete. Akwete is a unique hand woven fabric mainly spun by women in Akwete town of Abia state. It comes in different motifs-the patterns ranges from plain stripped to heavily pattern ones. The signification and connotation evoked by a particular Akwete depends largely on the motifs in the akwete. In Ijele, akwete are largely used to depict important characters.

Ijele: Ijele is the young hunter from whose name this film's title is derived. He is an epitome of the Igbo young man of the ancient traditional Igbo society- full of strength and valour. As a day old infant, he is shown swaddled in white oja (shawl) made of agbo. Agbo is another variant of akwete fabric mainly worn by the Omambala people of Anambra state. The film does not show anything on his growing up, but transcend into his adult age. $\mathrm{He}$ is then shown as a hunter dressed in white arm-band made of hide, 
white wrist-band also made with hide, a long stick (his hunting tool), hair band, ogodo (loin cloth) made with white leopard skin, spotted with black. On his waist is worn a pouch which bears his arrows and other hunting tools. His chest is adorned with a black and white animal skin shield embellished with three cowries. Cowries in the Igbo ancient times, served as a system of currency. Thus in this film it is used to portray Ijele as a successful hunter. The number three is symbolic in Igbo cultural milieu - three is the number of Ikenga (an Igbo deity). Among the Igbo people, Ikenga comprises of someone's chi (guardian angel), right hand as well as spiritual activation through prayer and sacrifice. Thus the three cowries worn by Ijele are symbolic to his character and occupation as they symbolize his Ikenga who always comes to his aid in the form of an old man. His entire costume made with animal skin depicts his occupation as a hunter. His back shielded with a whole animal skin portrays him as a successful hunter.

As the winner of the wrestling competition of that year and the defender of Obiligwe community, the king decorates Ijele with a lion's hide and a head gear made with animal skin. King's choice of lion's skin to decorate a wrestling champion here is also symbolic. This also goes a long way to portray his actual occupation. At home, he wears only his loin-clothe made with hide. He is bared of accessories. Thus the costume designer uses costume here to indicate place and situation.

Oma: Oma is a young maiden. She is usually clad in white akwete tied in the Igbo maiden's fashion. That is, a mini wrapper tied from the waist through the thigh (just slightly below the buttocks). A scanty size of the same material is wrapped around the breast and knotted at the back. This breast clothe is tied over the breasts and both ends of the clothes are knotted at the back. She is wearing about five strings of jigida. Her costumes depict modesty and homeliness. All her costumes are worn just in the Igbo maiden style.

\section{Princess Oladinma (the Self-Imposed Priestess of Olammiri} Shrine): She is the daughter of Igwe who collaborates with the community Diviner to install herself as the Priestess of the rain even when the goddess evidently rejects her. 
Okadigwe: Asserting the Dominance of Igbo Cultural ...

She is shown coming to see her father the Igwe in his obi. Her hair is aesthetically decorated with dark red and green beads. Her waist is embellished with cords of pink, green and dark red jigida. Her clothe is a white akwete designed with dark red and green motifs, two tiny brown horizontal lines running across the motifs. She is wearing two strings of neck beads. She looks hopeful and full of life.

During the "test period", which is before her installment as the priestess of the rain, she is seen with her acolytes in the street. Indigenes are seen already revering her as the chosen priestess. She seems very elated about this new development. She is adorned with a maxi blood red chiffon wrapper seemly designed with green wool and white cowries. The beautifications of her clothe goes beyond revealing her present status and extend to digging out her aspirations and ambitions. The colour red shows her passion for her elevated status from the community secular princess to her dearly anticipated spiritual leader. Lyndersay describing the significance of colour in Igbo costumes posits that, "Red signifies beauty on the one hand and a feeling of sacredness, danger and authority on the other." (417) White decorations on her clothe draws attention to her assumed connection to the goddess. White and red in the Igbo cultural background relate to spirituality. Authenticating this claim about the significance of white in Igbo traditional dress culture, Lyndersay accordingly quotes Dureke thus, "...white, seen as innocence and purity, was used for religious purposes, weddings, and by worshippers of the river goddess..." (417) Cowries are very significant to the Igbo sacred milieu, although they served as means of exchange in the Igbo ancient times. Her top is also red chiffon with straps for sleeves, designed with white cowries. This blouse is arrayed with a fish motif. This pattern is symbolic to her character as priestess of the rain because rain fall aids the river to yield abundance. This will in turn make the inhabitants of water to flourish. The fish motif is very symbolic to her social status. She is holding a big red hand fan to complement her social status. This hand fan is a symbol of authority within the Igbo cultural environment. She complements her look with strings of white wristbeads, white choker neck beads and her hair is beautified with strings of beads. 
On the day of the final test for the approval of Ola-mmiri goddess and the final prove that she is the priestess of the rain, her costumes reflect sacredness as it is obtained in the Igbo tradition. She is garbed in white cotton knee-length wrapper tied on the chest and knotted at the back. Her hair is adorned with cowries and red beads. She is wearing white strings of waist- beads, white strings of wrists-beads and brown choker neck beads. The colour brown relates to the earth and her status as priestess of the rain is very significant to the fertility of the earth. Without rain fall the earth may cease to yield fruits in abundance.

After her installation as the priestess of the rain, she begins to carry $n z a$. Nza is a cultural Igbo item symbolizing authority and leadership. The nza here imbues her with authority. She continues to wear her red chiffon but this time it is arrayed with small round mirrors. Mirror is a spiritual item in the Igbo sacred environment. She is wearing an arm band adorned with mirror. On the day ofigba$m g b a$ festival, she wears a wrapper variegated with white and red.

On her visit to Ijele's house, she is holding a white $n z a$ which is smaller than that of her father the Igwe. She is dressed in a black agbo designed with dark red and silver horizontal lines. Her waist is adorned with dark green jigida. Her neck is embellished with string of white cowries. She visits Ijele a second time at night with the aim of seducing him. She is in dazzling white akwete designed with silver and purple horizontal lines. Here her akwete is a micro mini wrapper. Contrary to ankle-length wrapper she usually wears, this time her wrapper is tied in the Igbo maiden style. Her waist is beautified with dark red jigida. Her neck beads are bright red in colour, tiny in size but fuller than the previous ones she wears. Her hair is attractively beautified with white cowries, pink and red beads. Her legs are painted in $n z u$. Nzu in Igbo cosmology, along with kola nut and palm wine is an item of prayer and could be used in invoking the ancestors. It is also used for beautification especially by those who have relations with deities. This analysis of Costumes culture in the film Ijelehas so far shown that the Igbo dress culture has largely contributed to the formation of the dress culture of the film. The film clearly draws its costume culture from the Igbo traditional dress culture. 
Okadigwe: Asserting the Dominance of Igbo Cultural ...

\section{Igbo cultural Patterns in the Costumes of the Priestess}

The Priestess is a Nollywood film produced by $\mathrm{O}$. Godwin Innovation Limited, costumed by Andy Offia and directed by Ilochi Olisaemeka in 2016. The film shows the greedy and selfish desires of one of the king's cabinet member (Urenma's father). The basic theme of The Priestess is the corrupting influence of this man on the community's suppliant (Ezemmou). Urenma's father is interested in his daughter's emergence as the Prince's choice of wife during the maidens' dance.

All the male adult characters in The Priestess wear anklelength wrappers made either of george, ankra or akwete fabrics. A variety of Igbo traditional costume was employed for the costuming of this film. Two ankle-length wrappers, headdress, jigida, wristbeads, uli makeup, bow and arrow, neck-beads, george, walking stick, hand-fan, cap, red and white clothes are worn by the actors depending on the gender, social and economic status of the characters they are playing. These costumes seem to have followed quite closely the clothes normally worn by Igbo people of the traditional Igbo period.

Since the film contains references to chieftaincy, Igbo traditional religious system, and to distinctions in clothing between the young and the old, the film depicts that costumes varied considerably. The film shows that plain white or red cotton fabrics are reserved for suppliants and diviners. While formal and informal traditional Igbo attires are used for other characters. An ankle or knee-length/thigh-length wrapper was the usual casual clothe for Igbo-men and young-men respectively.

Igwe's Cabinet Members: Igwe's cabinet members are usually shown in plane white and black chequered george attire worn in the Igbo men fashion. The chequered george fabrics are passed under the right arm-pit and then tied over the left shoulder. During each meeting with Igwe at his palace, his cabinet members are shown wearing a woolen cap. One eagle feather is attached to the woolen red, black and white striped cap with pompom on the top of the hat. Each of them holds a fashionable walking stick. Their arms are designed with uli patterns. The individual members are shown outside the palace wearing different sorts of traditional attires 
Ogirisi: a new journal of African studies vol. 15s 2019 ranging from the Igbo form of jumpers, laces and other synthetic materials. Their heads are constantly graced with red hats.

Diviners (Ugbana and Ezemou): Ugbana is the Priestess from whom this film derives its title. While Ezemmou is the community's diviner with the gods. Each of these characters portrays the religious system of the traditional Igbo people. Their costumes are most of the time shown as red and white cotton costumes. The use of red in art often reflects themes of lust, war, and blood, this film also uses this colour to appropriately depict Ezemmou's lust for wealth. Costuming Ezemmou in red costumes as his signature colour suits his personality perfectly. Here, the colour red is a symbol of power. Lyndersay in her study of Igbo costumes, posits that "... red called mmee(bloody) was traditionally used by chief priests..." (417) Ugbana on her way to the stream to take her bathe wears one-piece short white wrapper tied from the waist, reaching to the knees and another white wrapper tied on the chest and knotted at the back. She also wears an exclusive white headgear decorated with white feathers. Her costumes reflect the supernormal world of the film. This film shows the Antagonist struggling against the curse laid on her as things keep turning against her. Hence the film is portrayed as one controlled by the supernatural. Ugbana's earrings, neck-beads and jigida are all white colours. Her staff is also white variegated with yellow lining. Ezemmou is mostly shown in red kpeteli(loosely gathered skirt) and a red danshiki evenly designed with white cowries. He is carrying oji (traditional spiritual staff carried by Igbo diviners). Ezemmou goes bare-footed

and wears the Igbo traditional woven red and white cap with pompom.

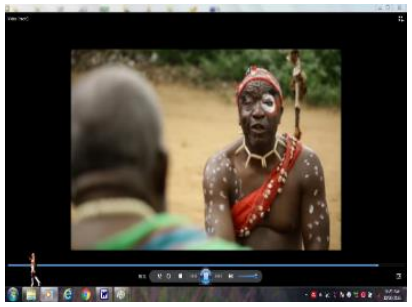

Picture 4: Suppliant costumed in cultural Igbo motifs comprising $n z u$ (native kaolin chalk), red cloth, red, black and white cap with pompom, and cowries. 
Okadigwe: Asserting the Dominance of Igbo Cultural ...
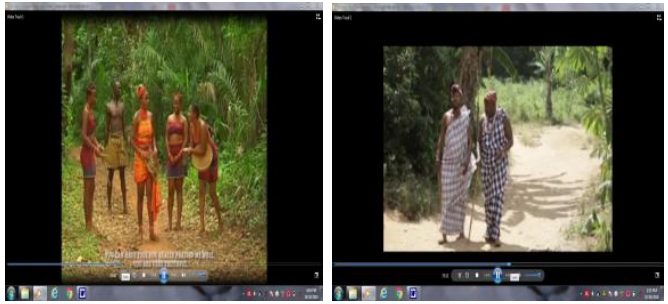

Pictures 5 and $\mathbf{6}$ show characters wearing Igbocultural attires depicting their various genders, age and marital status. Pictures are sourced from My Rising Sun and The Priestess respectively

\section{Conclusion}

Igbo cultural motifs are the prototype of Nollywood costumes. From the inception of Nollywood costumes, Igbo cultural motifs took dominant position in the creation of costumes. Lots of Nollywood films serve as valid evidence on the predominant presence of Igbo dress culture in Nollywood costumes. This research gathers that Igbo cultural motifs are usually used to create and define Nollywood characters. Outfits worn by Igbo people of the contemporary times appear to be adopted by Nollywood costume designers for the costuming of films set in the contemporary times. While those worn by the Igbo ancient people were adopted for epic and historic films. Hence, a variety of Igbo traditional cloths were found to be employed by Nollywood in costuming. Two ankle-length wrapper, knee-length or mini wrapper made with george, Ankara or akwete fabrics, jigida, $n z a$, and akah are worn by the actors/actresses depending on the gender, age, socio-economic and marital status of the character they are playing.

Married women are often shown in costume in Igbo traditional two wrappers. George and akwete fabrics with which Igbo people are identified are observed to be commonly used to costume female characters. Young unmarried girls are delineated with mini wrapper, while longer wrappers are used to indicate that a woman is a wife and mother. Depending on the period the film is set in, married women embody puffed-sleeve blouse, two wrappers and headdress. These costumes may have been typical of Igbo traditional eras, which have been modified with motifs from other cultures. It is common to also see Nollywood films set in a traditional milieu to 
show characters wearing the uli makeup of traditional Igbo people. Jigida, which is generally conceived as an Igbo item of beautification, seems to have evolved into a notable costume culture for costumiers.

It is also uncommon to see a maiden in Nollywood historic or epic films appearing without jigida. Maidens are mostly costumed in printed wax, akwete, plain, stripe and chequered george worn in the Igbo maiden fashion. That is, mini wrapper and a piece of the same fabric worn around the breasts. In almost all epic films, girls appear to be wearing at least a string of jigida, neck-beads, uli makeup design, earrings made either with cowries or beads.

My Rising Sun extensively employed the famous george material of the Igbo people. Akah which also portrays economic status in the Igbo traditional world are extensively employed for characterization. Elaborately embroidered george were used to indicate wealth, while plain chequered george were used to portray average characters. Male characters often appear to be shown in Igbo traditional cloths. Young men were observed to be costumed mostly in the traditional Igbo fashion of loin cloth that wrapped around their waists and between their legs then fastened at their backs. They are also seen in peteli. Peteli is a short gathered skirt or wrapper worn by young people in the Igbo ancient period. Older male characters usually appear in red cap, akah, printed wax or the famous isiagu fabric worn over trousers. For instance, the isiagu fabric of the Igbo people, traditional title-holder hat and knitted hat with pompom were extensively used in costuming the king's cabinet members in Festival of War (2015). Costumes in the Nollywood epic films usually seem to be pointing the Igbo traditional milieu.

It was also observed that most Nollywood films set in the city or contemporary times more often adopt the Igbo contemporary dress culture. That is, dress culture showing the integration of dress cultures from diverse cultures into the Igbo dress culture. The most obvious of the diverse dress culture being Western dress culture. This is exemplified in Festival of War and Better Tomorrow (See picture 1 above). These films show young girls dressed in Western style of skirt and blouse, tee-shirts and gowns, while mothers are dressed in boubou, tee-shirts, wrappers, buba of the Yoruba people. 
Okadigwe: Asserting the Dominance of Igbo Cultural ...

Nollywood costume designers also appeared to have been following costume design based on the ritual concerned as it is obtained in the Igbo traditional religious observances. For instance, Ubgana in The Priestess is shown in white attire worn in the Igbo maiden fashion, while Ezemuo in the same film is costumed in red peteli. White in the film defines purity and points to Ubgana's (priestess) connection to the water goddess. So just as in the Igbo traditional milieu, Nollywood seems to show that white and red cotton fabrics are reserved for supernatural characters (diviners). The research thus reveals that Igbo culture has played an important role in the formation of Nollywood costumes. The influence and impart of Igbo cultural motifs in the creation of Nollywood costume is evident in a mass of Nollywood films as this research has proved. Picture 8 Picture 9

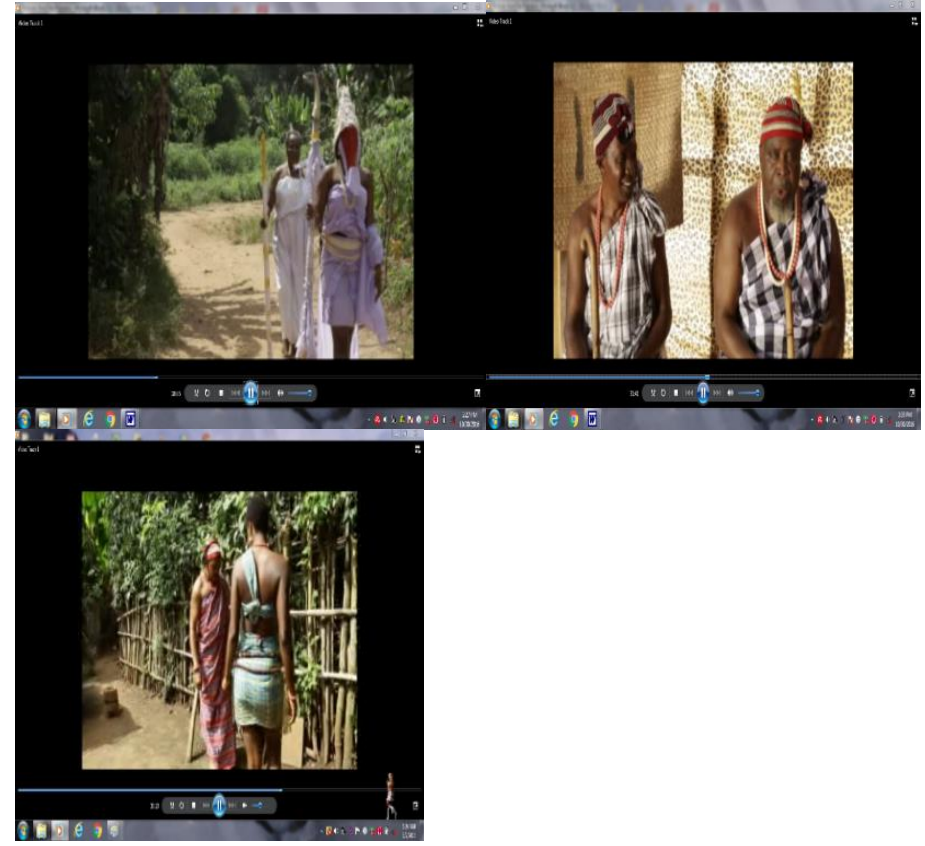

\section{Picture 10}

Picture 8 shows a priestess and her acolyte dressed in white wrappers tied in the Igbo maiden and mother's styles respectively. 
While Picture 9 shows elderly men wearing Igbo cultural costumes. Pictures 8, 9 and 10 were sourced from The Priestess, Festival of War and Ijele respectively.

\section{Recommendation}

This research recommends that Nollywood costumiers should focus more on the communicative elements of costumes. Costume and makeup designers in the industry should endeavour to give the actual depiction of clothes worn in the era. For instance, the practice of depicting traditional Igbo traditional characters uniformly with sack is wrong. They should take time to research into history and places before executing their designs. If the film is set in Igbo community, the costume designer should find out what Igbo people of that period wore. While the makeup artist, on his/her part; should try to find out the kind of makeup with which that period was identified. For instance, simulations of Ichi, which the traditional Igbo society used in depicting strength and valour could be used in heroic films to depict warriors and courageous men.

More costume scholars should engage in the research and documentation of cultural motifs and their significance. These can become reference point for the Nollywood costume designers.

\section{*Mary Nkechi Okadigwe, PhD}

Department of Theatre and Film Studies

NnamdiAzikiweUniversity, Awka, Nigeria.

Email: mn.okadigwe@unizik.edu.ng 
Okadigwe: Asserting the Dominance of Igbo Cultural ...

\section{References}

Ayakoroma, Barclays F. Trends in Nollywood: A Study of Selected Genres.Ibadan: Krafts Books Limited, 2014.

Berger, Arthur A. Seeing is Believing: An Introduction to Visual Communication 3rd Ed. New York: Mc Graw-Hill Companies, 2008.

Dan, Lyndersay. Nigerian Dress: The Body Honoured: The Costume Arts of Traditional Nigerian Dress from Early History to Independence: An Illustrated Source book for Nigerian Costume Design. Lagos: Centre for Black and African Arts and Culture, 2011.

Ejiofor, Asodionye B. "The History of Kalabari Men's Dressing in the Niger Delta" in Dress Culture and National Development. RasakiOjo B. and Barclays Foubiri A. (Eds.) Ibadan: Kraft Books Limited, 2011. 52-67.

Peirce, Charles S. Collected Papers. Harteshore C. and Weiss P.(eds). Cambridge, Mass: Harvard University Press, 19311958.

\section{FILMS CITED}

Ijele.Amata, Fred. Director. Prod. Great Movies Ind. Ltd., 1999

Festival of War.Jaja, Micheal. Director.Apex Global Link Productions Ltd., 2015.

Living in Bondage.Mordi, Vic. Director. 1992.

My Rising Sun. Odife, Iyke. Director.Stonegold Productions Ltd., 2016.

The Priestess. Olisaemaka, Iloch. Director. O. Godwin Innovation Ltd., 2016.

Better Tomorrow. Olisaemeka, Ilochi. Director. Priced Penny Production Ltd., 2016. 